\title{
Highly selective lipase-mediated discrimination of diastereomeric 5,6-epoxysteroids
}

\author{
M. Manuel Cruz Silva, ${ }^{a}$ Sergio Riva ${ }^{\mathrm{b}}$ and M. Luisa Sá e Melo, ${ }^{\mathrm{a}, *}$ \\ ${ }^{a}$ Centro de Estudos Farmacêuticos, Lab. Química Farmacêutica, Faculdade de Farmácia, Universidade de Coimbra, \\ Rua do Norte 3000-295, Coimbra, Portugal \\ ${ }^{\mathrm{b}}$ Istituto di Chimica del Riconoscimento Molecolare, C.N.R., Via Mario Bianco 9, 20131 Milano, Italy
}

Received 27 January 2004; accepted 11 February 2004

\begin{abstract}
Stereoisomerically pure 3 $\beta$-hydroxy-5,6-epoxysteroids were obtained by combining selective chemical methods for $\alpha$ - and

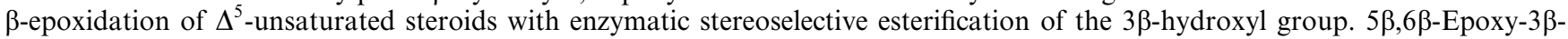
hydroxysteroids were efficiently acylated by Novozym 435 and lipase AK, whereas $5 \alpha, 6 \alpha$-epoxy-3 $\beta$-hydroxysteroids were good substrates for Candida rugosa lipase. Mild enzymatic deacylation of the $3 \beta$-acetoxy group in the presence of the epoxy functionality was also accomplished by $C$. rugosa lipase-mediated hydrolysis.

(c) 2004 Elsevier Ltd. All rights reserved.
\end{abstract}

\section{Introduction}

Steroid epoxides are an important group of oxysterols, which regulate many biological functions, such as cell proliferation and cholesterol homeostasis. ${ }^{1}$ For instance, $\alpha$ - and $\beta$-epoxides of cholesterol are bioactive autoxidation products, ${ }^{1,2}$ both being cytotoxic ${ }^{3}$ and mutagenic, ${ }^{4}$ while the $5 \beta, 6 \beta$-epoxy functionality is found in a number of naturally occurring steroids possessing antitumour activities, such as the withanolides. ${ }^{5}$ Furthermore, epoxides are synthetically valuable intermediates, since their facile ring opening allows the introduction of various functionalities in a stereospecific manner. ${ }^{6}$ These properties have attracted considerable attention for the stereoselective synthesis of $5 \alpha, 6 \alpha$-epoxides ( $\alpha$-epoxides) and $5 \beta, 6 \beta$-epoxides ( $\beta$-epoxides) on the steroid nucleus.

Epoxidation of $3 \beta$-substituted $\Delta^{5}$-steroids with peracids, ${ }^{7}$ such as 3 -chloroperoxybenzoic acid ( $m$-CPBA), is known to produce predominantly $\alpha$-epoxides due to the steric hindrance imposed by the $\mathrm{C}-10$ and $\mathrm{C}-13$ angular methyl groups. Current methods for the synthesis of $\beta$-epoxides include the use of halohydrins as intermediates, ${ }^{8}$ the use of 3-halo substituents to block the entry of reagents from the alpha face, ${ }^{9}$ chromyl diacetate, ${ }^{10}$ potassium permanganate/inorganic salts, ${ }^{11}$ chiral

\footnotetext{
* Corresponding author. Tel.: +351-239-859990; fax: +351-239-827030; e-mail: samelo@ci.uc.pt
}

ketones/oxone ${ }^{12}$ and transition metal complexes in the presence of air or molecular oxygen as oxidant. ${ }^{13}$

However, the majority of these methods fail to give diastereomerically pure $\alpha$ - and $\beta$-epoxides, thus more selective methods are still needed. Furthermore, the presence and stereochemistry of other substituents in the A- and B-rings can influence the stereoselectivity of the epoxidation method. ${ }^{1 \mathrm{a}, 13 \mathrm{~b}, 14}$

Generally the methods used to prepare $\beta$-epoxides require the appropriate protection of other hydroxyl groups present on the molecule. Chemical deprotection, quite often of an ester, can be hampered by the sensitivity of the oxirane group towards the usual hydrolytic conditions. As a consequence, the synthesis of $5 \beta, 6 \beta-$ epoxy-hydroxysteroids remains a difficult task.

Recently, biocatalysis, often being complementary to conventional chemical reactions, has become an effective tool for achieving mild and selective transformations. ${ }^{15}$ In particular, enzyme catalysis has played an important role for the selective interconversion of functional groups on the steroid structure. ${ }^{16,17}$ For example, studies on the enzymatic regioselective esterification of hydroxyl groups located at different positions of the skeleton have shown a preference of lipases for OH's at the C-3 position and of the protease subtilisin Carlsberg for the hydroxyl groups on the D ring. ${ }^{18}$ Moreover, the influence of the $\mathrm{A} / \mathrm{B}$ rings junction (cis or trans) and of $\Delta^{4}$ - or 
$\Delta^{5}$-unsaturations on the lipases specifically towards 3-hydroxy steroids has also been demonstrated. ${ }^{18,19}$

In order to provide diastereomerically pure $\alpha$ - or $\beta$-epoxysteroids by taking advantage of the known selectivity of enzymes towards steroidal substrates, we investigated the ability of lipases to discriminate between such epoxides through the acylation or deacylation of a hydroxyl moiety at the $3 \beta$-position. Additionally, the mild reaction conditions, provided by enzyme catalysis, were explored for the hydrolysis of $3 \beta$-acetoxy esters in the presence of the epoxy functionality.

\section{Results and discussion}

\subsection{Chemical synthesis of epoxides}

$\alpha$-Selective epoxidations of both $3 \beta$-hydroxy- and $3 \beta$-acetoxy- $\Delta^{5}$-unsaturated stereoids were performed with magnesium monoperoxyphthalate hexahydrate (MMPP), which is safer and easier to remove than common peracids, like $m$-CPBA. ${ }^{20}$ Furthermore, $\beta$-selective epoxidation of $3 \beta$-acetoxy- $\Delta^{5}$-unsaturated steroids can be carried out through the low cost and ecofriendly ${ }^{11}$ heterogeneous permanganate oxidation, following a procedure developed by our group. ${ }^{11 \mathrm{~b}}$ The $\alpha / \beta$ ratio of epoxides was determined by the integration of the $\mathrm{H}-6$ proton signal in the ${ }^{1} \mathrm{H}$ NMR spectra, which is known to appear as a doublet at around $2.9 \mathrm{ppm}$ $(J=4 \mathrm{~Hz})$ in the $\alpha$ isomer and as a doublet at $3.1 \mathrm{ppm}$ $(J=2 \mathrm{~Hz})$ in the $\beta$ isomer. ${ }^{21,13 \mathrm{a}}$ As expected, the diastereomeric excesses ranged between $70 \%$ and $80 \%$.

\subsection{Stereoselective lipase-catalysed esterification of $3 \beta$ - hydroxy-5,6-epoxysteroids to produce diastereomerically pure $\alpha$-epoxides}

The lipase-catalysed esterification of a $3 \beta$-hydroxy group in the presence of a 5,6-epoxy functionality was studied by screening the performances of a range of 14 commercial hydrolases using diastereomerically enriched 5,6-epoxycholestan-3 $\beta$-ol $1(\alpha / \beta$ ratio 83:17) and 5,6-epoxy-3 $\beta$-hydroxypregnan-20-one $\quad 2 \quad(\alpha / \beta$ ratio
90:10) as substrates (Scheme 1, left side). Under irreversible transesterification ${ }^{22}$ conditions (using vinyl acetate as the acyl donor and toluene as the solvent), TLC monitoring allowed the identification of a small group of lipases active on these substrates. Almost complete conversion of $\mathbf{1}$ was observed with Candida rugosa lipase, suggesting a good activity of this enzyme for the predominant $\alpha$-isomer, whereas minor conversion was noticed with Novozym 435, Chromobacterium viscosum lipase, lipase AK and lipase PS. Later on, the stereoselectivity of this group of lipases was more accurately measured by monitoring the acylation of the diastereomerically pure $\alpha$-epoxide $\mathbf{1 a}$ and $\beta$-epoxide $\mathbf{1 b}$ of cholesterol (obtained as described below) by GC. As shown in Table 1, the stereopreference of Novozym 435 for the acylation of the $3 \beta-\mathrm{OH}$ of the $\beta$-epoxide $\mathbf{1 b}$ was very high, while two different commercial preparations of $C$. rugosa lipase confirmed a significant preference for the $\alpha$-epoxy isomer 1a (first two entries of Table 1).

By exploiting these results, Novozym 435 was employed in preparative scale reactions to remove the minor $\beta$-isomer in $\alpha$-enriched mixtures of 3 $\beta$-hydroxy-5,6-epoxysteroids (Scheme 1, left hand side). In all cases, the unreacted $\alpha$-epoxides, 1a, 2a and 3a, were obtained in good isolated yields $(67-72 \%)$ and $100 \%$ diastereomeric excesses, as confirmed by ${ }^{1} \mathrm{H}$ NMR analysis.

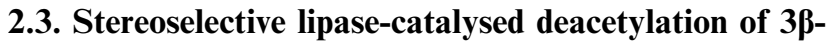 acetoxy-5,6-epoxysteroids to produce diastereomerically pure $\beta$-epoxides}

The next step was to find a suitable methodology for obtaining the complementary pure $\beta$-epoxides from the $\beta$-enriched mixtures of the corresponding acetates 4-6 prepared through permanganate epoxidation. ${ }^{11 \mathrm{~b}}$ Initially the stereoselective deacetylation of epimeric $3 \beta$-acetoxy-5,6-epoxysteroids was investigated using 1 -octanol as an acyl acceptor in alcoholysis reactions (Scheme 1, right hand side). Exploiting the stereopreference of $C$. rugosa lipase for $\alpha$-epoxides (Table 1, lines $1-2)$, preparative scale reactions were run in the presence of lipase AY in order to remove the minor $\alpha$-epoxide in mixtures 4-6. As expected, the unreacted 3-O-acetoxy $\beta$-epoxides $\left(\mathbf{1}^{\prime} \mathbf{b}, \mathbf{2}^{\prime} \mathbf{b}\right.$ and $\left.\mathbf{3}^{\prime} \mathbf{b}\right)$ were obtained in good

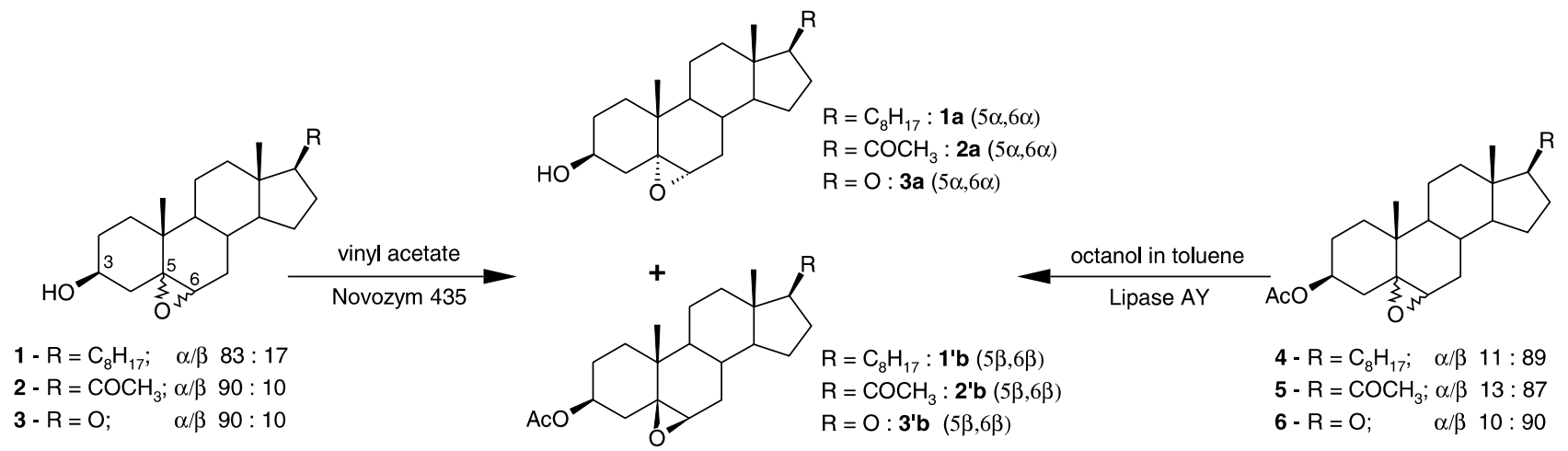

Scheme 1. Novozym 435-catalysed stereoselective acetylation of 3 $\beta$-hydroxy-5,6-epoxysteroids and lipase AY-catalysed stereoselective alcoholysis of $3 \beta$-acetoxy-5,6-epoxysteroids. 
Table 1. Lipase-catalysed acetylation of $\mathbf{1 a}$ and $\mathbf{1 b}$

\begin{tabular}{|c|c|c|c|c|c|}
\hline & \multirow[b]{2}{*}{ Substrate $^{\mathrm{b}}$} & \multicolumn{4}{|c|}{ Conversion $(\%)^{\mathrm{a}}$} \\
\hline & & $90 \mathrm{~min}$ & $3 \mathrm{~h}$ & $6 \mathrm{~h}$ & $24 \mathrm{~h}$ \\
\hline \multirow[t]{2}{*}{ C. rugosa lipase (Sigma) $3 \mathrm{mg}$} & $1 \mathbf{a}$ & 62.3 & 84.8 & 86.5 & 96.4 \\
\hline & $1 \mathbf{b}$ & 3.9 & 6.5 & 9.8 & 12.7 \\
\hline \multirow[t]{2}{*}{ Lipase $\mathrm{AY}^{\mathrm{c}}$ (Amano) $1.5 \mathrm{mg}$} & $1 \mathbf{a}$ & 80.8 & 90.5 & 92 & 96.3 \\
\hline & $1 \mathbf{b}$ & 2.5 & 6.3 & 7.8 & 9.8 \\
\hline \multirow[t]{2}{*}{ Novozym $435^{\mathrm{d}} 10 \mathrm{mg}$} & $1 \mathbf{a}$ & 0 & 0 & 0 & 1 \\
\hline & $1 \mathbf{b}$ & 14.3 & 26.4 & 47.9 & 82.3 \\
\hline \multirow[t]{2}{*}{ Lipase PS (Amano) $5 \mathrm{mg}$} & $1 \mathrm{a}$ & 10.2 & 23.7 & 33 & 71.4 \\
\hline & $1 \mathrm{~b}$ & 13.7 & 27.9 & 50 & 88.2 \\
\hline \multirow[t]{2}{*}{ Lipase $\mathrm{AK}^{\mathrm{f}}$ (Amano) $3 \mathrm{mg}$} & $1 \mathrm{a}$ & 1.7 & 2.4 & 4.3 & 11.9 \\
\hline & $1 \mathbf{b}$ & 15.2 & 29.6 & 53.1 & 90.6 \\
\hline \multirow[t]{2}{*}{ C. viscosum lipase (Finnsugar) $30 \mathrm{mg}$} & $1 \mathbf{a}$ & 0 & 0 & 0 & 4.6 \\
\hline & $1 \mathbf{b}$ & 4.5 & 9.6 & 16.7 & 41.7 \\
\hline
\end{tabular}

${ }^{\mathrm{a}}$ Evaluated by GC.

${ }^{\mathrm{b}} 10 \mathrm{mM} 5 \alpha, 6 \alpha$ - or $5 \beta, 6 \beta$-Epoxycholestan-3 $\beta$-ol, $\mathbf{1 a}$ or $\mathbf{1 b},(4 \mathrm{mg} / \mathrm{ml})$ in toluene with $10 \% \mathrm{v} / \mathrm{v}$ vinyl acetate.

${ }^{\mathrm{c}}$ From C. rugosa.

${ }^{\mathrm{d}}$ From $C$. antarctica.

${ }^{\text {e }}$ From P. cepacia.

${ }^{\mathrm{f}}$ From P. fluorescens.

isolated yields $(62-75 \%)$ and $100 \%$ diastereomeric excess, as confirmed by ${ }^{1} \mathrm{H}$ NMR analysis. On the other hand, quite unexpectedly, neither Novozym 435 nor any other tested lipases were able to catalyse the selective alcoholysis of the $3 \beta$-acetoxy group of $\beta$-epoxides.

\subsection{Mild nonselective lipase-catalysed deacetylation of $3 \beta$-acetoxy-5,6-epoxysteroid mixtures}

As a final step, we searched for reaction conditions able to promote a nonselective enzymatic alcoholysis, or hydrolysis, of the $3 \beta$-acetoxy group in epimeric 5,6-epoxysteroid mixtures (i.e., to transform 4-6 into 7-9). In fact, a mild deacylation protocol is of synthetic value since most of the methods used to prepare $5 \beta, 6 \beta$-epoxides are only applicable to 3-O-acylated substrates, and the subsequent chemical deacylation by standard procedures usually affect also the sensitive epoxy groups.

The lack of selectivity shown by lipase PS in the acylation of these substrates (Table 1) suggested that this lipase might be the enzyme of choice to accomplish the requested mild deacylation reaction. Unfortunately, this lipase did not accept $3 \beta$-acetoxy epoxysteroids as substrates in alcoholysis under hydrolysis reactions.
Therefore, we turned our attention again to C. rugosa lipase, as this enzyme showed a minor activity towards the $\beta$-epoxide epimers (Table 1 ). Careful optimisation of the reaction conditions indicated that water-saturated diisopropyl ether (DIPE) was the optimal system for performing the required deacylation in the presence of both $\alpha$ - and $\beta$-5,6-epoxides. Accordingly, scale-up reactions allowed complete enzymatic hydrolysis of the $3 \beta$-acetate in the epimeric mixtures $4 \mathbf{- 6}$ without affecting the sensitive epoxides to give the corresponding alcohols 7-9 (Scheme 2).

The $\beta$-enriched mixture of 5,6-epoxides of cholesterol 7 thus obtained was submitted to AY-catalysed stereoselective acylation in order to remove the minor $\alpha$-epoxide, rendering diastereomerically pure $5 \beta, 6 \beta$-epoxycholestan-3 $\beta$-ol 1b (Scheme 3), which was used to study the stereoselectivity of lipases to $\mathbf{1 a}$ and $\mathbf{1 b}$ by GC analysis (Table 1).

\section{Conclusion}

Herein we have reported the further usefulness of lipases for the selective modification of steroids. Specifically,

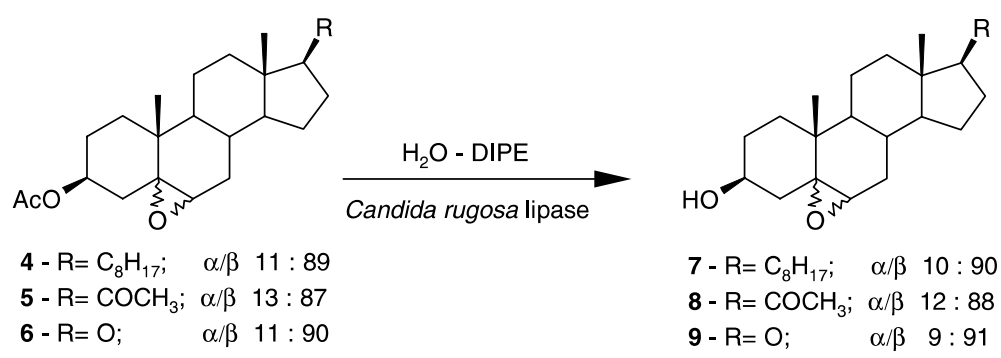

Scheme 2. C. rugosa lipase-catalysed mild deacylation of $3 \beta$-acetoxy-5,6-epoxysteroids. 


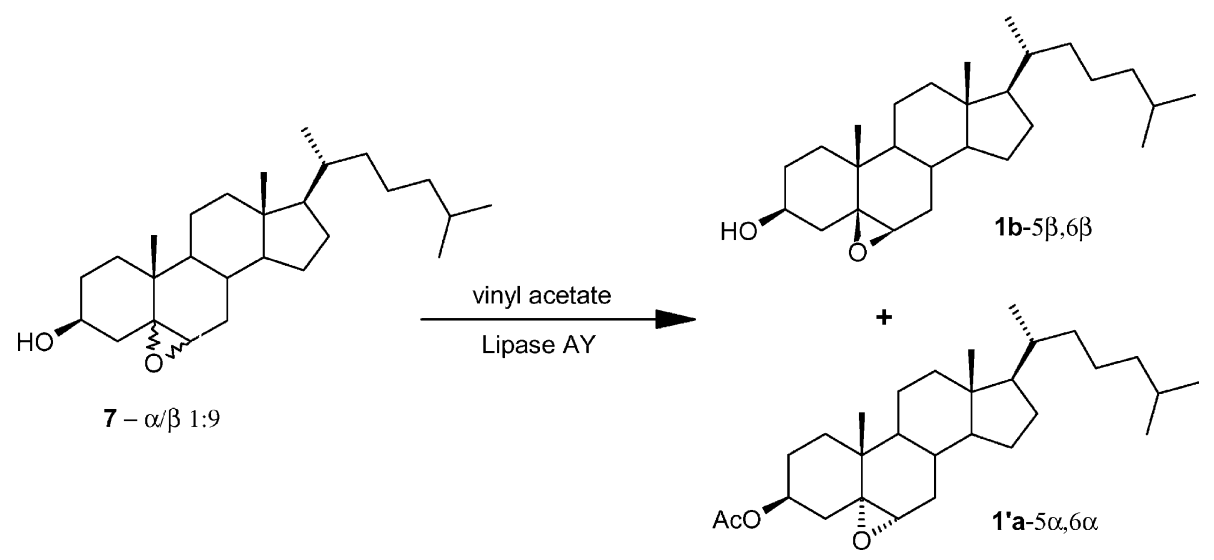

Scheme 3. Lipase AY-catalysed stereoselective acetylation of 5,6-epoxycholestane-3ß-ol 7.

diastereomerically pure $\alpha$-epoxides can be obtained by exploiting the strict selectivity of Novozym 435 for the minor $\beta$-epoxides components of epimeric mixtures. This biotransformation not only confirms the selectivity of this lipase, originally isolated from the yeast Candida antarctica, but is also a new noteworthy example of selectivity control by remote stereocentres. ${ }^{23}$

The screening of a library of commercially available lipases also indicated that the enzyme from C. rugosa lipase has an opposite selectivity compared to Novozym 435 , thus allowing the isolation of diastereomerically pure $\beta$-epoxides via alcoholysis reactions.

Finally, a mild and clean deacylation reaction of the $3 \beta$ acetoxy group in the presence of the sensitive 5,6-epoxy moiety was attained using C. rugosa lipase as catalyst and water as nucleophile.

\section{Experimental}

\subsection{General}

All commercially available chemicals were used as supplied by the manufacturers. Steroids and crude C. rugosa lipase were from Sigma. Novozym 435 (immobilised C. antarctica lipase B) and Lypozyme IM 20 were from Novo Nordisk. Lipase PS (from Pseudomonas cepacia) was purchased from Amano and adsorbed on Celite as described elsewhere. ${ }^{24}$ Lipase AK (from Pseudomonas fluorescens) and lipase AY (from C. rugosa) were from Amano. C. viscosum lipase was supplied by Finnsugar. ${ }^{1} \mathrm{H}$ NMR and ${ }^{13} \mathrm{C}$ NMR spectra were recorded on a Bruker AC-300 at 300 and $75.47 \mathrm{MHz}$, respectively, using $\mathrm{CDCl}_{3}$ as a solvent. Chemical shifts are reported on the $\delta(\mathrm{ppm})$ scale and are relative to tetramethylsilane as the internal standard. Infrared spectra were recorded on a Jasco FT/IR-420 spectrometer. Optical rotations were determined on a Jasco P-1020 polarimeter. Melting points were measured in a Büchi B-540. TLC monitoring was done in toluene/diethyl ether (85:15) as eluent, and detected using Komarowsky's reagent. ${ }^{25}$ The degrees of conversion were determined by gas chromatography using a Hewlett Packard 5890 series II instrument, a HP-1 Crosslinked Methyl Silicone Gum ( $25 \mathrm{~m}, 0.32 \mathrm{~mm}$ ID, Hewlett Packard), oven temperatures ranging from 236 to $290^{\circ} \mathrm{C}$ and $\mathrm{H}_{2}$ as the carrier gas.

\subsection{Chemical synthesis of $5 \alpha, 6 \alpha$ - and $5 \beta, 6 \beta$-epoxysteroids}

4.2.1. Representative procedure for the epoxidation of 3及hydroxy $-\Delta^{5}$ unsaturated steroids with MMPP. To a solution of the $3 \beta$-hydroxy- $\Delta^{5}$-unsaturated steroid $(1 \mathrm{mmol})$ in $\mathrm{CH}_{2} \mathrm{Cl}_{2}(10 \mathrm{ml})$ and ethanol $(2 \mathrm{ml})$, magnesium monoperoxyphthalate hexahydrate (MMPP, $990 \mathrm{mg}, 2 \mathrm{mmol}$ ) was added and the suspension stirred at room temperature for $24 \mathrm{~h}$. After this time the reaction was shown to have gone to completion (TLC control). Then, sodium chloride and diethyl ether were added and the suspension filtered through Celite. The filtrate was washed with $5 \% \mathrm{HCl}$, satd $\mathrm{NaHCO}_{3}$, water and brine, dried over $\mathrm{MgSO}_{4}$ and evaporated to dryness, giving the $\alpha$-enriched epimeric mixtures of the epoxides as the only products.

Compound 1: ${ }^{1} \mathrm{H}$ NMR $\delta: 0.61\left(3 \mathrm{H}, \mathrm{s}, \mathrm{CH}_{3}-18\right), 1.06$ $\left(3 \mathrm{H}, \mathrm{s}, \mathrm{CH}_{3}-19\right), 2.91$ and $3.07(1 \mathrm{H}, \mathrm{d}$ each, $J=4.362$ and $2.190 \mathrm{~Hz}$, respectively, H-6), $3.90(1 \mathrm{H}, \mathrm{m}, \mathrm{H}-3)$. The integration of the two signals (doublet peaks) due to the H-6 proton gave a 8.3:1.7 $\alpha / \beta$ ratio. ${ }^{13} \mathrm{C}$ NMR $\delta: 59.33$ (C-3), 65.77 (C-5), 68.70 (C-6). IR (ATR): $v_{\max }$ 1038.48, 1366.3, 1465.6, 2864.7, 2931.3, $3395 \mathrm{~cm}^{-1}$.

Compound 2: ${ }^{1} \mathrm{H}$ NMR $\delta$ : $0.56\left(3 \mathrm{H}, \mathrm{s}, \mathrm{CH}_{3}-18\right), 1.00$ $\left(3 \mathrm{H}, \mathrm{s}, \mathrm{CH}_{3}-19\right), 2.03\left(3 \mathrm{H}, \mathrm{s}, \mathrm{CH}_{3}-21\right), 2.92$ and 3.08 $(1 \mathrm{H}, \mathrm{d}$ each, $J=4.359$ and $2.352 \mathrm{~Hz}$, respectively, H-6), $3.90(1 \mathrm{H}, \mathrm{m}, \mathrm{H}-3)$. The integration of the two signals (doublet peaks) due to the H-6 proton gave a 9:1 $\alpha / \beta$ ratio. ${ }^{13} \mathrm{C}$ NMR $\delta: 59.06(\mathrm{C}-3), 63.33$ (C-17), 65.67 (C-5), 68.58 (C-6), 209.52 (C-20). IR (ATR): $v_{\max }$ 1049.1, $1355,1684,1700.9,2930.3,3437.5 \mathrm{~cm}^{-1}$.

Compound 3: ${ }^{1} \mathrm{H}$ NMR $\delta$ : $0.82\left(3 \mathrm{H}, \mathrm{s}, \mathrm{CH}_{3}-18\right), 1.09$ $\left(3 \mathrm{H}, \mathrm{s}, \mathrm{CH}_{3}-19\right), 2.95$ and $3.13(1 \mathrm{H}, \mathrm{d}$ each, $J=4.329$ and $2.532 \mathrm{~Hz}$, respectively, H-6), $3.90(1 \mathrm{H}, \mathrm{m}, \mathrm{H}-3)$. The 
integration of the two signals (doublet peaks) due to the H-6 proton gave a 9:1 $\alpha / \beta$ ratio. ${ }^{13} \mathrm{C}$ NMR $\delta: 58.75(\mathrm{C}-$ 3), 65.72 (C-5), 68.49 (C-6), 220.68 (C-17). IR (ATR): $v_{\max } 1027.9,1725.0,2944.8,3518 \mathrm{~cm}^{-1}$.

4.2.2. Representative procedure for the epoxidation of $3 \beta$ acetoxy- $\Delta^{\mathbf{5}}$-unsaturated steroids with $\mathrm{KMnO}_{4}$ /inorganic salts. To a solution of the $3 \beta$-acetoxy- $\Delta^{5}$-unsaturated steroid $(1 \mathrm{mmol})$ in $\mathrm{CH}_{2} \mathrm{Cl}_{2}(5 \mathrm{ml})$, a mixture of finely powdered $\mathrm{KMnO}_{4}(350 \mathrm{mg})$ and $\mathrm{Fe}_{2}\left(\mathrm{SO}_{4}\right)_{3} \cdot\left(\mathrm{H}_{2} \mathrm{O}\right)_{n}$ $(175 \mathrm{mg})$ was added. Then, water $(75 \mu \mathrm{l})$ and $t$-butyl alcohol $(0.5 \mathrm{ml})$ were added and the reaction mixture left overnight at room temperature under magnetic stirring. After this time the reaction was shown to have gone to completion (TLC control). Sodium chloride and diethyl ether were added and the suspension was filtered through Celite. The filtrate was evaporated to dryness, giving the $\beta$-enriched epimeric mixtures of the epoxides as the only products.

Compound 4: ${ }^{1} \mathrm{H}$ NMR $\delta$ : $0.64\left(3 \mathrm{H}, \mathrm{s}, \mathrm{CH}_{3}-18\right), 1.00$ (3H, s, $\left.\mathrm{CH}_{3}-19\right), 2.03\left(3 \mathrm{H}, \mathrm{s}, \mathrm{CH}_{3} \mathrm{CO}\right), 2.90$ and 3.08 $(1 \mathrm{H}, \mathrm{d}$ each, $J=4.371$ and $1.941 \mathrm{~Hz}$, respectively, H-6), $4.77(1 \mathrm{H}, \mathrm{m}, \mathrm{H}-3)$. The integration of the two signals (doublet peaks) due to the H-6 proton gave a 1.1:8.9 $\alpha / \beta$ ratio. ${ }^{13} \mathrm{C}$ NMR $\delta$ : $59.14(\mathrm{C}-6), 65.15$ (C-5), $71.36(\mathrm{C}-3)$, $170.21\left(\mathrm{CH}_{3} \mathrm{CO}\right) . \mathrm{IR}(\mathrm{ATR}): v_{\max } 1030.8,1243.9,1363.4$, $1465.6,1731.8,2866.7,2933.2 \mathrm{~cm}^{-1}$.

Compound 5: ${ }^{1} \mathrm{H}$ NMR $\delta$ : $0.59\left(3 \mathrm{H}, \mathrm{s}, \mathrm{CH}_{3}-18\right), 1.01$ (3H, s, $\left.\mathrm{CH}_{3}-19\right), 2.03\left(3 \mathrm{H}, \mathrm{s}, \mathrm{CH}_{3} \mathrm{CO}\right), 2.11\left(3 \mathrm{H}, \mathrm{s}, \mathrm{CH}_{3}-\right.$ 21), 2.91 and $3.09(1 \mathrm{H}$, d each, $J=4.347$ and $2.163 \mathrm{~Hz}$, respectively, H-6), 4.77 (1H, m, H-3). The integration of the two signals (doublet peaks) due to the H-6 proton gave a 1.3:8.7 $\alpha / \beta$ ratio. ${ }^{13} \mathrm{C}$ NMR $\delta: 62.42(\mathrm{C}-5), 63.35$ $(\mathrm{C}-17), 63.60$ (C-6), 71.19 (C-3), $170.55 \quad\left(\mathrm{CH}_{3} \mathrm{CO}\right)$, 209.37 (C-20). IR (ATR): $v_{\max }$ 1029.8, 1243.9, 1356.7, $1698.9,1735,2930.0 \mathrm{~cm}^{-1}$.

Compound 6: ${ }^{1} \mathrm{H}$ NMR $\delta$ : $0.85\left(3 \mathrm{H}, \mathrm{s}, \mathrm{CH}_{3}-18\right), 1.04$ (3H, s, $\left.\mathrm{CH}_{3}-19\right), 2.04\left(3 \mathrm{H}, \mathrm{s}, \mathrm{CH}_{3} \mathrm{CO}\right), 2.94$ and 3.15 (1H, d each, $J=4.341$ and $2.493 \mathrm{~Hz}$, respectively, H-6), $4.77(1 \mathrm{H}, \mathrm{m}, \mathrm{H}-3)$. The integration of the two signals (doublet peaks) due to the H-6 proton gave a 0.9:9.1 $\alpha / \beta$ ratio. ${ }^{13} \mathrm{C} \mathrm{NMR} \delta$ : $62.56(\mathrm{C}-5), 63.17$ (C-6), $71.10(\mathrm{C}-3)$, $170.53\left(\mathrm{CH}_{3} \mathrm{CO}\right), 220.77(\mathrm{C}-17)$. IR (ATR): $v_{\max } 1029.8$, $1240.0,1727.9,2946.7 \mathrm{~cm}^{-1}$.

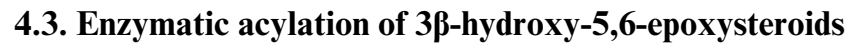

In a typical screening assay, $3 \beta$-hydroxy-5 $\alpha, 6 \alpha$-epoxy- or $3 \beta$-hydroxy- $5 \beta, 6 \beta$-epoxy-steroid $(10 \mathrm{mg})$ dissolved in toluene $(0.9 \mathrm{ml})$ and vinyl acetate $(0.1 \mathrm{ml})$ was added to the enzyme (50 mg of crude enzymes, $10 \mathrm{mg}$ of Lypozyme IM 20 or $10 \mathrm{mg}$ of Novozym 435) in $3 \mathrm{ml}$ vials. The vials were stopped with a cap and shaken at $250 \mathrm{rpm}$ at $45^{\circ} \mathrm{C}$. The reactions were monitored by TLC and GC (see Table 1).

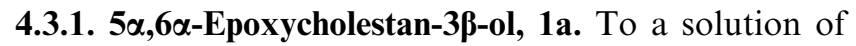
5,6-epoxycholestan-3 $\beta$-ol 1 (150 $\mathrm{mg}, \alpha / \beta$ ratio 8.3:1.7) in toluene $(8.5 \mathrm{ml})$ and vinyl acetate $(1.5 \mathrm{ml})$, Novozym 435 $(75 \mathrm{mg})$ was added and the reaction shaken at $45^{\circ} \mathrm{C}$. After $24 \mathrm{~h}$ the enzyme was filtered off and the solvent evaporated. 5 $\alpha, 6 \alpha$-Epoxycholestan-3 $\beta$-ol 1a (100 mg, $67 \%$ yield) was isolated by flash chromatography (petroleum ether/ethyl acetate $1: 1$ ) as a single diastereomer $[\alpha]_{\mathrm{D}}^{21}=-44.5,\left(c 0.5, \mathrm{CHCl}_{3}\right)\left\{\right.$ lit. $\left.^{26}[\alpha]_{\mathrm{D}}=-47\right\}$, $\mathrm{mp} 141.5-142.7^{\circ} \mathrm{C}$ (lit. $\left.{ }^{26} 141-142{ }^{\circ} \mathrm{C}\right)$ as indicated by ${ }^{1} \mathrm{H}$ NMR.

4.3.2. $5 \alpha, 6 \alpha-E p o x y-3 \beta$-hydroxypregnan-20-one, $2 \mathrm{a}$. To a solution of 5,6-epoxy-3 $\beta$-hydroxypregnan-20-one 2 (150 $\mathrm{mg}, \alpha / \beta$ ratio $9.1: 0.9)$ in toluene $(8.5 \mathrm{ml})$ and vinyl acetate $(1.5 \mathrm{ml})$, Novozym $435(75 \mathrm{mg})$ was added and the reaction shaken at $45^{\circ} \mathrm{C}$. After $24 \mathrm{~h}$ the enzyme was filtered off and the solvent evaporated. $5 \alpha, 6 \alpha$-epoxy-3 $\beta$ hydroxypregnan-20-one $\mathbf{2 a}$ (108 $\mathrm{mg}, 72 \%$ yield) was isolated by flash chromatography (petroleum ether, ethyl acetate $1: 1)$ as a single diastereomer $[\alpha]_{\mathrm{D}}^{21}=+6.35$, (c $\left.0.84, \mathrm{CHCl}_{3}\right)\left\{\right.$ lit. $\left.^{27}[\alpha]_{\mathrm{D}}=+1\right\}, \operatorname{mp} 179.2-182.0^{\circ} \mathrm{C}$ (lit. ${ }^{27} 190-191{ }^{\circ} \mathrm{C}$ ), as indicated by ${ }^{1} \mathrm{H}$ NMR.

4.3.3. $5 \alpha, 6 \alpha-E p o x y-3 \beta$-hydroxyandrostan-17- one, 3a. To a solution of 5,6-epoxy-3 $\beta$-hydroxyandrostan-17-one (3, $150 \mathrm{mg} \alpha / \beta$ ratio $9: 1)$ in toluene $(8.5 \mathrm{ml})$ and vinyl acetate $(1.5 \mathrm{ml})$, Novozym $435(75 \mathrm{mg})$ was added and the reaction was shaken at $45^{\circ} \mathrm{C}$. After $24 \mathrm{~h}$ the enzyme was filtered off and the solvent was evaporated. $5 \alpha, 6 \alpha-$ Epoxy-3 $\beta$-hydroxyandrostan-17-one (3a, $103 \mathrm{mg}, 69 \%$ yield) was isolated by flash chromatography (petroleum ether/ethyl acetate $1: 1.5)$ as a single diastereomer $\left\{[\alpha]_{\mathrm{D}}^{21}=-4.3, c 0.5, \mathrm{CHCl}_{3}, \operatorname{mp} 225-228^{\circ} \mathrm{C}\right.$ (lit. ${ }^{9 \mathrm{~b}} 227-$ $\left.\left.230{ }^{\circ} \mathrm{C}\right)\right\}$, as indicated by ${ }^{1} \mathrm{H}$ NMR.

\subsection{Enzymatic deacylation of $3 \beta$-acetoxy-5 $\alpha, 6 \alpha-$ and $5 \beta, 6 \beta$-epoxysteroids}

In a typical screening assay, the $3 \beta$-acetoxy-5 $\alpha, 6 \alpha$ epoxy- or $3 \beta$-acetoxy- $5 \beta, 6 \beta$-epoxy-steroid ( $10 \mathrm{mg}$ ) having been dissolved in toluene $(0.9 \mathrm{ml})$ and octanol $(0.1 \mathrm{ml})$, were added to the enzyme $(50 \mathrm{mg}$ of crude enzymes, $10 \mathrm{mg}$ of Lypozyme IM 20 or $10 \mathrm{mg}$ of Novozym 435) in $3 \mathrm{ml}$ vials. The vials were stopped with a cap and shaken at $250 \mathrm{rpm}$ at $45^{\circ} \mathrm{C}$. The reactions were monitored by TLC over 5 days.

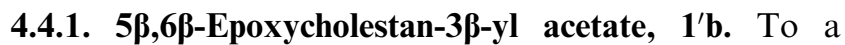
solution of 5,6-epoxycholestan-3 $\beta$-yl acetate 4 (180 mg, $\alpha / \beta$ ratio $1.1: 8.9)$ in toluene $(8 \mathrm{ml})$ and octanol $(2 \mathrm{ml})$, lipase AY (200 mg) was added and the reaction shaken at $45^{\circ} \mathrm{C}$. After 3 days, the enzyme was filtered off and solvent was evaporated. 5 $3,6 \beta$-Epoxycholestan-3 $\beta$-yl acetate $\mathbf{1}^{\prime} \mathbf{b}$ (112 $\mathrm{mg}, 62 \%$ yield) was isolated by flash chromatography (petroleum ether/ethyl acetate $2: 1$ ) as a single diastereomer $[\alpha]_{\mathrm{D}}^{21}=-0.57,\left(c 1.09, \mathrm{CHCl}_{3}\right)\left\{\right.$ lit. $^{28}$ $\left.[\alpha]_{\mathrm{D}}=-0.2\right\}, \mathrm{mp} 109-111^{\circ} \mathrm{C}$ (lit. ${ }^{28} 112-113^{\circ} \mathrm{C}$ ), as indicated by ${ }^{1} \mathrm{H}$ NMR. 


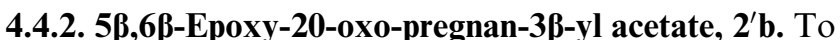
a solution of 5,6-epoxy-20-oxo-pregnan-3 $\beta$-yl acetate $\mathbf{5}$, $(180 \mathrm{mg}, \alpha / \beta$ ratio $1.3: 8.7)$ in toluene $(8 \mathrm{ml})$ and octanol $(2 \mathrm{ml})$, lipase AY $(200 \mathrm{mg})$ was added and the reaction shaken at $45^{\circ} \mathrm{C}$. After 3 days, the enzyme was filtered off and the solvent was evaporated. $5 \beta, 6 \beta$-Epoxy-20-oxopregnan-3 $\beta$-yl acetate $\mathbf{2}^{\prime} \mathbf{b}$ (126 mg, 70\% yield) was isolated by flash chromatography (petroleum ether/ethyl acetate $2: 1)$ as a single diastereomer. $[\alpha]_{\mathrm{D}}^{21}=+50.6,(c$ $\left.1.18, \mathrm{CHCl}_{3}\right)\left\{\right.$ lit. $\left.^{8 \mathrm{a}}[\alpha]_{\mathrm{D}}=+50\right\}, \mathrm{mp} 132-134{ }^{\circ} \mathrm{C}$ (lit. ${ }^{8 \mathrm{a}}$ $\left.132-136^{\circ} \mathrm{C}\right)$, as indicated by ${ }^{1} \mathrm{H}$ NMR.

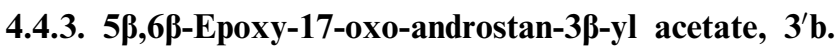
To a solution of 5,6-epoxy-17-oxo-androstan-3 $\beta$-yl acetate $6(180 \mathrm{mg}, \alpha / \beta$ ratio $1: 9)$ in toluene $(8 \mathrm{ml})$ and octanol $(2 \mathrm{ml})$, lipase AY $(200 \mathrm{mg})$ was added and the reaction shaken at $45^{\circ} \mathrm{C}$. After 3 days, the enzyme was filtered off and the solvent evaporated. $5 \beta, 6 \beta$-Epoxy-17oxo-androstan-3 $\beta$-yl acetate $\mathbf{3}^{\prime} \mathbf{b}$ (135 mg, 75\% yield) was isolated by flash chromatography (petroleum ether/ethyl acetate $1: 1)$ as a single diastereomer, $[\alpha]_{\mathrm{D}}^{21}=+43.0$, ( $c$ 1.4, $\left.\mathrm{CHCl}_{3}\right)\left\{\right.$ lit. $\left.^{29}[\alpha]_{\mathrm{D}}=+40.5\right\}, \mathrm{mp} 186.7-188^{\circ} \mathrm{C}$ (lit. $^{29}$ $185-187^{\circ} \mathrm{C}$ ), as indicated by ${ }^{1} \mathrm{H}$ NMR.

\subsection{Total hydrolysis of $3 \beta$-acetoxy-5 $\alpha, 6 \alpha$ - and $5 \beta, 6 \beta-$ epoxysteroids}

In a typical experiment, the $3 \beta$-acetoxy-5,6-epoxysteroid $(150 \mathrm{mg})$, obtained by permanganate epoxidation, was dissolved in diisopropyl ether $(35 \mathrm{ml})$ presaturated with water and then $C$. rugosa lipase $(1.8 \mathrm{~g})$ added. The mixture was shaken at $250 \mathrm{rpm}, 45^{\circ} \mathrm{C}$ and after 3 days the reactions were shown to have gone to completion. The products were isolated and the $\alpha / \beta$ ratios quantified by ${ }^{1} \mathrm{H}$ NMR: 5,6-epoxycholestan-3 $\beta$-ol 7 (136 mg, $\alpha / \beta$ ratio 1:9), 5,6-epoxy-3 $\beta$-hydroxypregnan-20-one $\mathbf{8}$ $(130 \mathrm{mg}, \alpha / \beta$ ratio $1.2: 8.8)$ and 5,6 -epoxy-3 $\beta$-hydroxyandrostan-17-one 9 (135 $\mathrm{mg}, \alpha / \beta$ ratio 0.9:9.1).

\section{6. $5 \beta, 6 \beta-E p o x y c h o l e s t a n-3 \beta-o l ~ 1 b$}

To a solution of 5,6-epoxycholestan-3 $\beta$-ol 7 (136 mg, $\alpha / \beta$ ratio $1: 9)$ in toluene $(6 \mathrm{ml})$ and vinyl acetate $(1 \mathrm{ml})$, Lipase AY $(100 \mathrm{mg})$ was added and the reaction shaken at $45^{\circ} \mathrm{C}$. After 3 days the enzyme was filtered off and the solvent evaporated. $5 \beta, 6 \beta$-Epoxycholestan- $3 \beta$-ol $\mathbf{1 b}(100.5 \mathrm{mg}$, $74 \%$ yield) was isolated by flash chromatography (petroleum ether/ethyl acetate 1:1) as a single diastereomer, $[\alpha]_{\mathrm{D}}^{21}=+8.0,\left(c 0.5, \mathrm{CHCl}_{3}\right)\left\{\right.$ lit. $\left.^{29}[\alpha]_{\mathrm{D}}=+7.8\right\}, \mathrm{mp}$ 127-129 ${ }^{\circ} \mathrm{C}$ (lit. $.^{29} 128-131{ }^{\circ} \mathrm{C}$ ), as indicated by ${ }^{1} \mathrm{H}$ NMR.

\section{Acknowledgements}

Thanks are due to Fundação para a Ciência e Tecnologia (FCT) partly through POCTI (FEDER) and to the CNR-GRICES bilateral exchange program (2003-2004) for financial support. M. M. Cruz Silva wishes to thank Fundação Calouste Gulbenkian for a Ph.D. grant.

\section{References and notes}

1. (a) Guardiola, F.; Codony, R.; Addis, P. B.; Rafecas, M.; Boatella, J. Fd. Chem. Toxic. 1996, 34, 193-211; (b) Smith, L. L. Lipids 1996, 31, 453-487.

2. Hwang, P. L. BioEssays 1991, 13, 583-589.

3. (a) O'Callaghan, Y. C.; Woods, J. A.; O'Brien, N. M. Cell Biol. Toxicol. 2001, 17, 127-137; (b) O'Sullivan, A. J.; O'Callaghan, Y. C.; Woods, J. A.; O'Brien, N. M. J. Appl. Toxicol. 2003, 23, 191-197.

4. (a) Blackburn, G. M.; Rashid, A.; Thompson, M. H. J. Chem. Soc., Chem. Commun. 1979, 9, 420-421; (b) Sevanian, A.; Peterson, A. R. Proc. Natl. Acad. Sci. 1984, 81, 4198-4202; (c) Raaphorst, G. P.; Azzam, E. I.; Langlois, R.; van Lier, J. E. Biochem. Pharmacol. 1987, 36, 2369-2372.

5. (a) Kupchan, S. M.; Anderson, W. K.; Bollinger, P.; Doskotch, R. W.; Smith, R. M.; Renauld, J. A. S.; Schnoes, H. K.; Burlingame, A. L.; Smith, D. H. J. Org. Chem. 1969, 34, 3858-3866; (b) Habtemariam, S. Planta Medica 1997, 63, 15-17; (c) Habtemariam, S.; Skelton, B. W.; Waterman, P. G.; White, A. H. J. Natl. Prod. 2000, 63, 512-513; (d) Jayaprakasam, B.; Zhang, Y.; Seeram, N. P.; Nair, M. G. Life Sciences 2003, 74, 125-132.

6. Smith, J. G. Synthesis 1984, 8, 629-656.

7. Kirk, D. N.; Hartshorn, M. P. In Steroid Reaction Mechanism; Eabrorn, C., Chapman, N. B., Eds.; Elsevier: London, 1968; p 69.

8. (a) Akhtar, M.; Barton, D. H. R. J. Am. Chem. Soc. 1964, 86, 1528-1536; (b) Matthews, G. J.; Hassner, A. In Organic Reactions in Steroid Chemistry; Fried, J., Edwards, J. A., Eds.; Van Nostrand Reinhold Company: New York, 1972; 2, p 1

9. (a) Shiota, M.; Ogihara, T.; Watanabe, Y. Bull. Chem. Soc. Jpn. 1961, 34, 40-42; (b) Hanson, J. R.; Truneh, A. J. Chem. Soc., Perkin Trans. 1 1988, 2001-2003.

10. (a) Galagovsky, L. R.; Gros, E. G. J. Chem. Res. (S) 1990, 366-367; (b) Galagovsky, L. R.; Gros, E. G. J. Chem. Res. (S) 1993, 137.

11. (a) Syamala, M. S.; Das, J.; Baskaran, S.; Chandrasekaran, S. J. Org. Chem. 1992, 57, 1928-1930; (b) Salvador, J. A. R.; Sá e Melo, M. L.; Campos Neves, A. S. Tetrahedron Lett. 1996, 37, 687-690; (c) Singh, N.; Lee, D. G. Org. Proc. Res. Dev. 2001, 5, 599-603.

12. Yang, D.; Jiao, G.-S. Chem. Eur. J. 2000, 6, 3517-3521.

13. (a) Marchon, J.-C.; Ramasseul, R. Synthesis 1989, 5, 389391; (b) Tavarès, M.; Ramasseul, R.; Marchon, J.-C.; Bachet, B.; Brassy, C.; Mornon, J.-P. J. Chem. Soc., Perkin Trans. 2 1992, 1321-1329; (c) Kesavan, V.; Chandrasekaran, S. J. Org. Chem. 1998, 63, 6999-7001; (d) Zhang, J.-L.; Zhou, H.-B.; Huang, J.-S.; Che, C.-M. Chem. Eur. J. 2002, 8, 1554-1562.

14. (a) Mousseron-Canet, M.; Labeeuw, B.; Lanet, J.-C. Bull. Soc. Chim. France 1968, 5, 2125-2130; (b) Hanson, J. R.; Terry, N.; Uyanik, C. J. Chem. Res. (S) 1998, 50-51; (c) Hanson, J. R.; Hitchcock, P. B.; Kiran, I. J. Chem. Res. (S) 1999, 538-539.

15. (a) Carrea, G.; Riva, S. Angew. Chem., Int. Ed. 2000, 39, 2226-2254; (b) Koeller, K. M.; Wong, C.-H. Nature 2001, 409, 232-240; (c) Riva, S. Curr. Opin. Chem. Biol. 2001, 5, 106-111; (d) Thomas, S. M.; DiCosimo, R.; Nagarajan, V. Trends in Biotech. 2002, 20, 238-242.

16. (a) Njar, V. C. O.; Caspi, E. Tetrahedron Lett. 1987, 28, 6549-6552; (b) Adamczyk, M.; Chen, Y.-Y.; Fishpaugh, J. R.; Gebler, J. C. Tetrahedron: Asymmetry 1993, 4, 14671468; (c) Baldessari, A.; Maier, M. S.; Gros, E. G. Tetrahedron Lett. 1995, 36, 4349-4352; (d) Danieli, B.; Lesma, G.; Luisetti, M.; Riva, S. Tetrahedron 1997, 53, 5855-5862; (e) Secundo, F.; Carrea, G.; De Amici, M.; 
Joppolo di Ventimiglia, S.; Dordick, J. S. Biotechnol. Bioeng. 2003, 81, 391-396.

17. (a) Ferraboschi, P.; Molatore, A.; Verza, E.; Santaniello, E. Tetrahedron: Asymmetry 1996, 7, 1551-1554; (b) Ferraboschi, P.; Reza-Elahi, S.; Verza, E.; Santaniello, E. Tetrahedron: Asymmetry 1998, 9, 2193-2196; (c) Ferraboschi, P.; Pecora, F.; Reza-Elahi, S.; Santaniello, E. Tetrahedron: Asymmetry 1999, 10, 2497-2500; (d) Ferraboschi, P.; Colombo, D.; Reza-Elahi, S. Tetrahedron: Asymmetry 2002, 13, 2583-2586.

18. (a) Riva, S.; Klibanov, A. M. J. Am. Chem. Soc. 1988, 110, 3291-3295; (b) Ottolina, G.; Carrea, G.; Riva, S. Biocatalysis 1991, 5, 131-136.

19. (a) Riva, S.; Bovara, R.; Ottolina, G.; Secundo, F.; Carrea, G. J. Org. Chem. 1989, 54, 3161-3164; (b) Bertinotti, A.; Carrea, G.; Ottolina, G.; Riva, S. Tetrahedron 1994, 50, 13165-13172.

20. (a) Brougham, P.; Cooper, M. S.; Cummerson, D. A.; Heaney, H.; Thompson, N. Synthesis 1987, 11, 1015-1017; (b) Heaney, H. Aldrichimica Acta 1993, 26, 35-45.
21. Cross, A. D. J. Am. Chem. Soc. 1962, 84, 32063207.

22. Wang, Y.-F.; Lalonde, J. J.; Momongan, M.; Bergbreiter, D. E.; Wong, C.-H. J. Am. Chem. Soc. 1988, 110, 72007205.

23. Angoli, M.; Barilli, A.; Lesma, G.; Passarella, D.; Riva, S.; Silvani, A.; Danieli, B. J. Org. Chem. 2003, 68, 95259527.

24. Cruz Silva, M. M.; Sá e Melo, M. L.; Parolin, M.; Tessaro, D.; Riva, S.; Danieli, B. Tetrahedron: Asymmetry 2004, 12, 21-27.

25. MacDonald, I. A. J. Chromatogr. 1977, 136, 348.

26. Houminer, Y. J. Chem. Soc., Perkin Trans. 1 1975, 1663 1669.

27. Ellis, B.; Petrow, V. J. Chem. Soc. 1956, 44174419.

28. Plattner, P. A.; Petrzilka, T.; Lang, W. Helv. Chim. Acta 1944, 27, 513-524.

29. Cubberley, B. W.; Marples, B. A. J. Chem. Soc., Perkin Trans. 1 1974, 9-13. 